\title{
PENGARUH MATERIAL BUTIR HALUS TERHADAP TINGKAT KEPADATAN CAMPURAN MATERIAL RESIDUAL
}

\author{
(The Effects of Fine Grained to a Density of a Residual Material Mixtures) \\ Christy Anandha Putri ${ }^{1}$ \\ ${ }^{1}$ Program Studi Teknik Sipil Universitas Trisakti \\ E-mail: christy.anandha@trisakti.ac.id
}

\begin{abstract}
ABSTRAK
Dalam pelaksanaan konstruksi, pemilihan, proses, serta hasil dari pemadatan sangat diperhatikan. Ketiga hal tersebut sangat mempengaruhi energi serta biaya yang digunakan. Karakteristik kepadatan, kekuatan, kompresibilitas, dan permeabilitas sangat dipengaruhi oleh kandungan butir kasar dan butir halus yang ada didalamnya. Adanya kandungan butir halus dalam material akan menimbulkan keberadaan mineral yang mengakibatkan peningkatan terhadap daya serap air. Sementara butir kasar didalam material akan cenderung memiliki tingkat kepadatan yang lebih tinggi. Penelitian ini mempelajari karakteristik pemadatan dari pengaruh kandungan butir halus dari campuran material residual. Material yang digunakan berasal dari Jawa Barat, yaitu tanah merah dari daerah Lagadar dan pasir dari daerah Padalarang. Penelitian ini menggunakan tujuh variasi presentase butir halus yang berbeda yaitu 10\%, 20\%, 30\%, 40\%, 50\%, 70\%, dan 100\%. Pengujian pemadatan laboratorium menggunakan Standard Proctor Compaction Test (ASTM D 698-91). Berdasasarkan hasil pengujian kompaksi diperoleh kepadatan maksimum (MDD) dari kandungan material butir halus 10\% hingga 100\% secara berturut-turut adalah $1.53,1.49,1.47,1.42,1.39,1.38$, dan $1.36 \mathrm{gr} / \mathrm{cm}^{3}$, sedangkan kadar air optimum yang membentuknya adalah $19 \%, 20 \%, 22.5 \%, 26 \%, 31 \%, 32 \%$, dan 34\%. Dari hasil tersebut dapat diketahui bahwa peningkatan presentase butir halus akan meningkatkan kadar air optimum (OMC) dan menurunkan nilai kepadatan maksimum (MDD). Presentase butir halus 10\%, 20\%, dan 30\% menghasilkan nilai MDD yang cenderung sama, yaitu dengan perbedaan 1.3\%. Berdasarkan hasil tersebut maka material dengan kandungan butir halus 10\% hingga 30\% direkomendasikan sebagai material yang direkomdasikan untuk pekerjaan timbunan.
\end{abstract}

Kata Kunci: Material residual, Butir Halus, Standard proctor, Material timbunan

\begin{abstract}
In the execution of construction, the selection, process, and results of compaction are very concerned. These three things greatly affect the energy and costs used. Characteristics of density, strength, compressibility, and permeability are strongly influenced by the content of coarse grains and fine grains in it. The presence of fine grain content in the material will cause the presence of minerals which results in an increase in water absorption. While coarse grains in the material will tend to have a higher density. This study examines compaction characteristics from the influence of fine grain content from a mixture of residual material. The material used came from West Java, namely red soil from Lagadar and sand from Padalarang. This study uses seven different percentages of fine grains,that is $10 \%, 20 \%$, 30\%, 40\%, 50\%, 70\%, and 100\%. Laboratory compaction testing using Standard Proctor Compaction Test (ASTM D 698-91). Based on the results of compacting test obtained the maximum density (MDD) from fine grain material content of $10 \%$ to $100 \%$ are $1.53,1.49,1.47,1.42,1.39,1.38$, and $1.36 \mathrm{gr} / \mathrm{cm} 3$, while the optimum water is $19 \%$, $20 \%, 22.5 \%, 26 \%, 31 \%, 32 \%$, and $34 \%$. From these results it can be seen that a percentage increase in fine grains will increase the optimum moisture content (OMC) and reduce the maximum density value (MDD). The percentage of fine grains is $10 \%, 20 \%$, and $30 \%$ resulting in MDD values that tend to be the same, with a difference of $1.3 \%$. Based on these results, material with fine grain content of $10 \%$ to $30 \%$ is recommended for material embankment.
\end{abstract}

Keywords: Residual material, Fine grained, Standard proctor, Material of embankment 


\section{PENDAHULUAN}

Keadaan tanah sangat beragam, hal tersebut dipengaruhi oleh lokasi, keadaan alam, serta batuan pembentuknya. Sebagian besar tanah berasal dari pelapukan dari berbagai jenis batuan. Secara umum pelapukan dapat dibedakan menjadi dua jenis, yaitu pelapukan mekanik dan pelapukan kimia. Proses pelapukan yang panjang menjadikan partikel tanah mempunyai ukuran dan karakteristik yang bervariasi. Pelapukan batuan murni membentuk material butir kasar antara lain batu pecah dan pasir. Sedangkan, pelapukan batuan secara kimiawi membentuk material butir halus baik lempung maupun lanau. Tanah yang terbentuk langsung akibat pelapukan kimiawi dan tetap berada pada tempat batuan asalnya disebut dengan tanah residual. Yang membedakan tanah residual dengan tanah sedimen adalah adanya mineral pembentuk yang terbentuk dari proses pelapukan kimia. Jenis mineral lempung yang dihasilkan pada suatu keadaan tertentu sangat tergantung pada batuan asal dan lingkungan pelapukan. Beberapa faktor yang mempengaruhi kandungan mineral tersebut antara lain iklim, topografi, dan nilai asam basa dari air yang mengaliri lokasi tersebut (Wesley, 2010).

Karakteristik kepadatan, kekuatan, kompresibilitas, dan permeabilitas sangat dipengaruhi oleh kandungan butir kasar dan halus yang ada didalamnya. Pemadatan merupakan usaha yang diberikan untuk mengurangi udara dalam tanah dengan menggunakan energi yang berbeda-beda sesuai dengan kebutuhan. Pada pekerjaan konstruksi jalan dan bendungan, pekerjaan pemadatan juga menggunakan material timbunan sebagai material tambahan lainnya untuk menggantikan material tanah asli sebagai usaha perbaikan. Material timbunan dipengaruhi oleh karakteristik daya dukung dan perubahan volume. Material timbunan merupakan material yang mendukung suatu perkuatan, sehingga tidak boleh menghasilkan deformasi. Sementara, perubahan volume akibat perilaku kembang susut dari kandungan air akan membuat struktur yang ada menjadi tidak stabil.

Terdapat beberapa penelitian yang mempelajari mengenai pengaruh kadar kandungan butir halus pada tanah campuran. Kim D., Sagong M, Lee Y (2005) mempelajari pengaruh kadar agregat halus terhadap properties mekanik material tanah granit. Dari pengujian tersebut dapat diketahui bahwa semakin tinggi kandungan butir halus pada material campuran, maka kepadatan maksimum yang dihasilkan semakin rendah, sementara kadar air optimum semakin tinggi. . Hasil penelitian yang dilakukan Sridharan A, Nagaraj H.B (2005) yang meyatakan tidak ada korelasi antara karakteristik pemadatan dengan nilai batas plastis yang dilakukan pada 10 tanah campuran. Penelitian yang dilakukan oleh Hopibulsuk S, Suddeepong A, Chinkulkijn A (2013) mengenai perilaku pemadatan pada tanah butir halus, tanah lateritik, dan batu pecah menyatakan bahwa usaha pemadatan mempengaruhi kepadatan, sehingga penggunaan material dapat mempertimbangkan sisi teknik dan ekonomi.
Berdasarkan penelitian Prasanna H. S, et.al (2017) menyatakan bahwa karakteristik pemadatan tanah dapat dikorelasikan dengan nilai batas cair dan batas plastisnya.

Pemadatan pada tanah butir kasar dan butir halus menggunakan metode yang berbeda, karena perbedaan karakteristik antara keduanya. Kandungan butir halus dalam material juga mempengaruhi kandungan mineral didalamnya yang akan meningkatkan kemampuan penyerapan air. Karakteristik kepadatan material dapat diketahui melalui pemodelan dalam skala yang lebih kecil dalam laboratorium. Nilai berat volume kering maksimum (MDD) dan kadar air optimum (OMC) akan menggambarkan tingkat kepadatan tanah. Kandungan material yang lebih dominan dalam tanah, akan mempengaruhi nilai MDD dan OMC. Pemilihan material timbunan juga berdasarkan kedua nilai tersebut, karena akan mempengaruhi deformasi, daya dukung, dan sifat kembang susut. Oleh karena itu, dalam tulisan ini membahas karakteristik pemadatan dari material campuran yang kemudian diberikan rekomendasi bagi material timbunan.

\section{METODOLOGI}

Berikut adalah bagan alir dari pelaksanaan penelitian yang dilaksanakan di laboratorium:

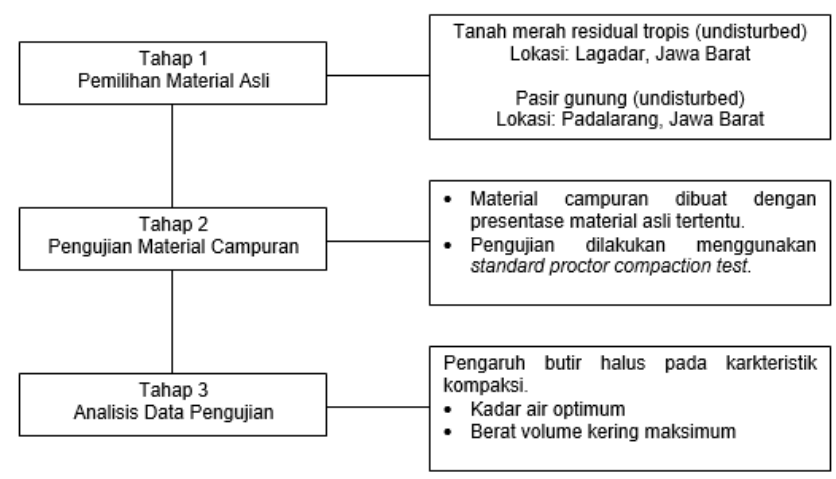

Gambar 1. Bagan alir penelitian

Pemilihan material asli: Tanah merah tropis yang digunakan diambil dari wilayah Lagadar, Jawa Barat. Lagadar merupakan daerah dimana merupakan pusat penambangan tanah merah yang biasa digunakan untuk timbunan berbagai pekerjaan konstruksi. Sementara pasir yang digunakan adalah jenis pasir gunung yang diambil dari wilayah Padalarang, Jawa Barat. Material tanah residual diambil dari kedalaman $0,5-1,0$ meter.

Pengujian material campuran: Pengujian agregat terbagi menjadi dua, yaitu agregat kasar untuk pasir dan agregat halus untuk tanah residu. Untuk mengetahui karakteristik masing-masing agregat, maka dilakukan beberapa pengujian. Untuk agregat kasar pengujian yang dilakukan meliputi specific gravity (Gs) dan analisa ukuran butir baik tapis maupun hidrometer. 


\section{Analisis data pengujian:}

Analisis data hasil pengujian yang dilakukan antara lain dari pengujian Gs, distribusi ukuran butir, berat volume kering maksimum (MDD), dan kadar air optimum (OMC). Berdasarkan nilai-nilai tersebut kemudian diberikan rekomendasi untuk material timbunan.

\section{PERSIAPAN DAN PENGUJIAN BENDA UJI}

Material asli: Untuk tanah residual, nilai Gs adalah 2,5771 serta kadar air natural $35,791 \%$. Sementara dari pengujian analisa ukuran butir diketahui material pembentuknya adalah pasir sebesar $10,4 \%$, lanau $68,435 \%$, dan lempung $21,165 \%$, seperti yang dapat dilihat pada Gambar 2. Berdasarkan presentase material pembentuk, tanah residual didominasi oleh lanau dan lempung, maka dapat dikatakan bahwa tanah residual termasuk kedalam material butir halus.

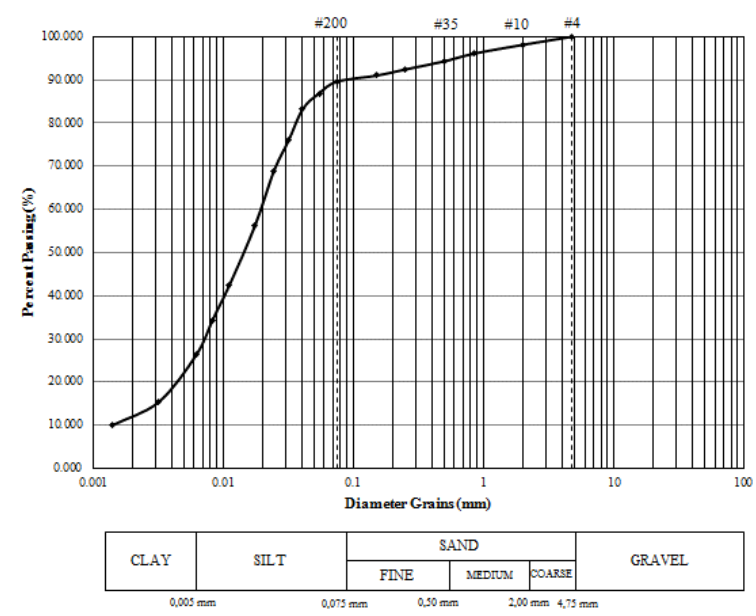

Gambar 2. Kurva distribusi ukuran butir tanah residual

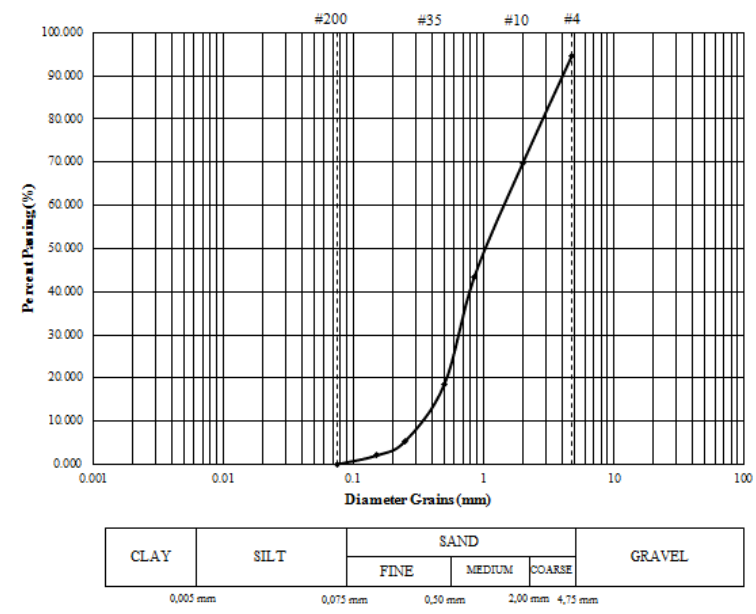

Gambar 3. Kurva distribusi ukuran butir pasir

Sementara hasil dari pengujian pasir, diperoleh nilai Gs sebesar 2,6504 dengan komposisi material pembentuk berupa batu pecah sebesar $5,530 \%$ dan pasir $94,470 \%$, seperti yang dapat dilihat pada Gambar 3. Pasir yang digunakan harus tidak memiliki kadar butir halus, sehingga sifat dan karakteristiknya mencerminkan material butir kasar. Butir halus dalam material pasir dihilangkan dengan cara dicuci pada saringan no.200 kemudian dikeringkan udara. Hasil xray difraksi yang dilakukan pada tanah residual menunjukkan bahwa mineral pembentuknya adalah kaolinite $42,5 \%$, cristobalite $24,1 \%$, quartz $21,3 \%$, dan anorthite 12,1\%, yang dapat dilihat pada Gambar 4 .

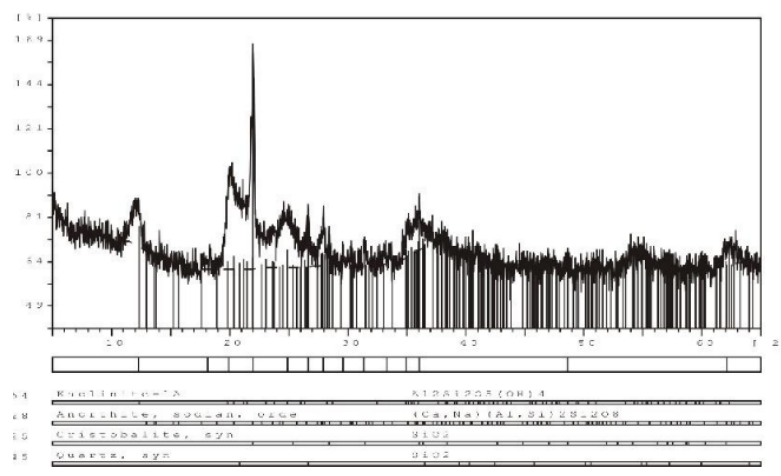

Gambar 4. Hasil pengujian difraksi x-ray pada tanah residual

Material uji: Benda uji merupakan material yang dibuat menggunakan campuran dua material asli dengan komposisi tertentu. Terdapat tujuh benda uji dengan variasi kadar tanah residual yang bebedabeda. Komposisi campuran material menggunakan perhitungan berat kering, dimana kadar air natural masing-masing agregat diperhitungkan. Variasi komposisi material untuk benda uji dapat dilihat pada Tabel 1.

Tabel 1. Komposisi kadar tanah residual dan pasir dalam pengujian

\begin{tabular}{|cc|c|c|c|c|c|c|}
\hline Material & \multicolumn{6}{c}{ Persentase Material Campuran } \\
\hline Tanah Residual & 10 & 20 & 30 & 40 & 50 & 70 & 100 \\
\hline Pasir & 90 & 80 & 70 & 60 & 50 & 30 & 0 \\
\hline
\end{tabular}

Pembuatan benda uji: Uji pemadatan menggunakan metode Standard Proctor yang mengacu pada ASTM D698-91. Benda uji dibentuk dari campuran tanah dan pasir kering udara dan lolos tapis No.4. Pasir dan tanah residual kemudian dicampur rata dengan menggunakan tangan secara manual. Setelah menjadi campuran yang homogen, kemudian dilakukan penambahan air sambil dicampur secara perlahan. Campuran tersebut kemudian dimasukkan kedalam plastik dan ditutup rapat selama \pm 24 jam, yang nantinya akan dilakukan uji pemadatan. Hasil dari uji pemadatan adalah berat volume kering maksimum dan kadar air optimum. Hal ini dilakukan untuk seluruh variasi.

\section{HASIL DAN PEMBAHASAN}

Properties dan karakteristik material asli: Berdasarkan ukuran butirnya, pasir memiliki gradasi yang baik karena terdiri dari keberagaman diameter yang ditunjukkan dengan tertahannya material pada 
setiap tapis. Sementara, berdasarkan nilai Gs yang dihasilkan, mineral kaolinite mempunyai kandungan yang dominan pada tanah residual. Hasil pengujian distribusi ukuran butir memberikan nilai presentase lolos saringan No.200 ( $\left.F_{200}\right)$ adalah 89,6\%. Berdasarkan Unified Soil Classification System (USCS) jika $F_{200}$ lebih besar dari 50\%, maka material dapat digolongkan kedalam butir halus yang meliputi lempung dan lanau. Jika dilihat dari nilai batas plastisitasnya, maka tanah residual termasuk kedalam lanau berplastisitas tinggi menurut bagan plastisitas Cassagrande.

Material campuran: Kurva hasil pengujian kompaksi tanah residual dan material campuran dapat dilihat pada Gambar 5, sementara nilai kadar air optimum dan berat volume kering maksimum diberikan padaTabel 2. Tanah residual mempunyai berat volume kering maksimum yang paling rendah. Semakin rendah presentase tanah residual dalam material campuran membuat nilai berat volume kering maksimum semakin besar. Kadar air optimum tanah residual mempunyai nilai yang paling tinggi diantara material campuran. Semakin rendah presentase tanah residual dalam suatu campuran, maka kurva kompaksi bergerak kearah kadar air yang semakin kecil yang merupakan indikasi nilai kadar air optimum yang menurun.

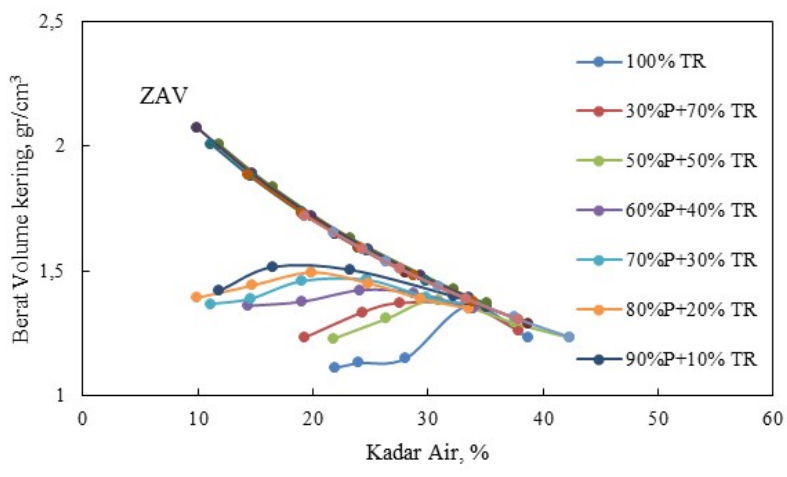

Gambar 5. Kurva kompaksi material uji

Tabel 2. Berat volume kering maksimum dan kadar air optimum dari material uji

\begin{tabular}{c|c|c|c|c|c|c|c}
\hline \multirow{2}{*}{ Material } & \multicolumn{6}{|c}{ Persentase Tanah Residual (\%) } \\
\cline { 2 - 8 } & 10 & 20 & 30 & 40 & 50 & 70 & 100 \\
\hline$\square_{\text {dry max }}$ & 1, & 1, & 1, & 1, & 1, & 1, & 1,3 \\
$\left(\mathrm{gr} / \mathrm{cm}^{3}\right)$ & 53 & 49 & 47 & 42 & 39 & 38 & 6 \\
\hline $\mathrm{W}_{\text {opt }}(\%)$ & 19 & 20 & $\begin{array}{r}22 \\
, 5\end{array}$ & 26 & 31 & 32 & 34 \\
\hline
\end{tabular}

Nilai kadar air optimum dan berat volume kering maksimum pada pemadatan dipengaruhi oleh beberapa faktor, antara lain ukuran butir, bentuk butiran tanah, specific gravity, dan kandungan mineral dalam material. Penurunan presentase tanah residual diiringi dengan menurunnya kandungan mineral kaolinite dalam campuran, hal ini membuat penyerapan air berkurang dan kadar air optimum semakin menurun. Penurunan presentase tanah residual diikuti dengan peningkatan presentase pasir, akibatnya terjadi perubahan ukuran butir menjadi ukuran yang lebih besar. Hal ini juga meningkatkan nilai specific gravity, maka berat volume kering maksimum akan semakin besar.

Kurva kompaksi untuk varisasi material seperti yang dapat dilihat pada Gambar 5 memiliki kecenderungan bentuk yang berbeda. Tanah butir halus memiliki kecenderungan untuk menyerap air sangat banyak, sehingga pada awal peningkatan kadar air berat volume keringnya meningkat secara perlahan, kemudian mencapai nilai maksimum, lalu turun secara signifikan. Berbeda halnya dengan bentuk lengkung cenderung lebih datar karena peningkatan nilai berat volume kering cenderung tidak signifikan.

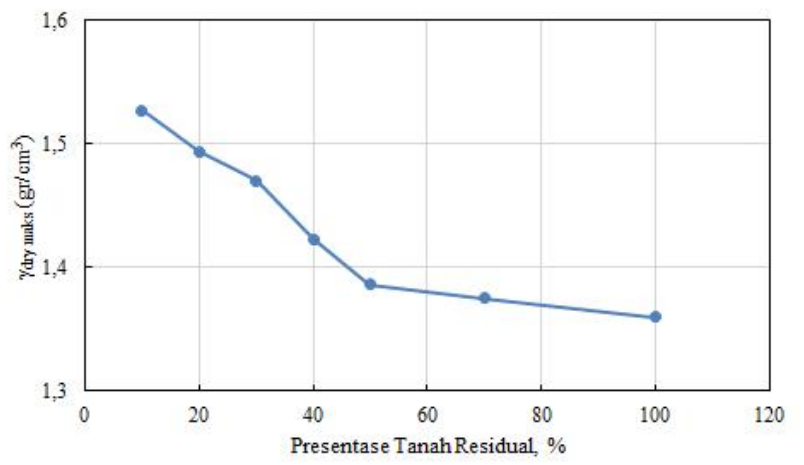

Gambar 6. Hubungan kepadatan maksimum dengan presentase butir halus

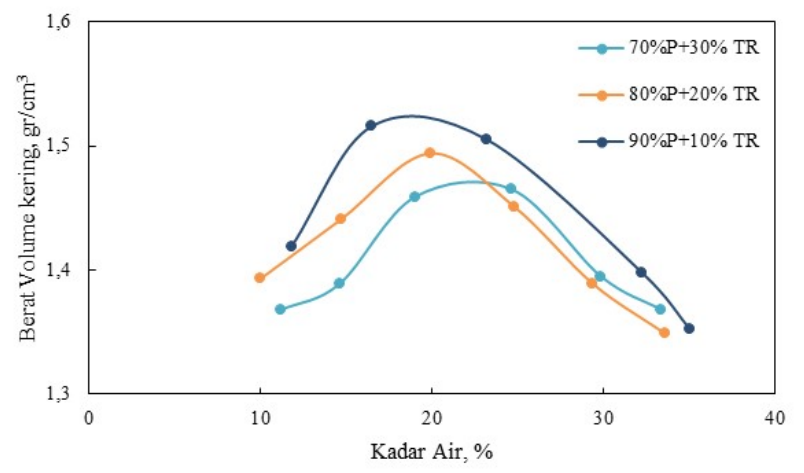

Gambar 7. Kurva pemadatan material campuran dengan prsentase tanah residual 10\% hingga 30\%

Nilai kepadatan maksimum dari variasi material campuran dapat dilihat pada Gambar 6, yang menunjukkan bahwa nilai berat volume kering maksimum masing-masing campuran berkurang seiring dengan meningkatnya presentase tanah residual. Berat volume kering maksimum yang dibentuk oleh presentase tanah residual 10\% hingga $30 \%$ cenderung memiliki nilai yang sama, dimana penurunan yang terjadi hanya $2 \%$ hingga $4 \%$. Berbeda halnya dengan material dengan presentase tanah residual 40\% sampai dengan 100\% yang mengalami penurunan lebih besar hingga mencapai 11\%. Dengan melihat kecenderungan berat volume kering maksimum yang dihasilkan oleh masing-masing material campuran, maka material 
dengan presentase tanah residual 10\% hingga 30\% dapat digunakan sebagai material timbunan yang baik. Dengan usaha pemadatan yang sama, menghasilkan kepadatan yang lebih tinggi. Sementara, jika menggunakan material dengan presentase tanah residual diatas 40\%, kepadatan yang dihasilkan cenderung menurun secara signifikan.

Tujuan pemadatan adalah untuk memberikan stabilitas dan perbaikan terhadap perilaku dari tanah yang akan digunakan. Berat volume kering dan kadar air mempunyai keterkaitan dengan parameter tanah yang akan dihasilkan. Secara umum, hasil pengujian laboratorium akan mengarahkan pada material yang akan digunakan untuk menunjang propertis yang telah direncanakan. Dari hasil pengujian laboratorium tersebut, kemudian berat volume kering maksimum yang dihasilkan dapat diaplikasikan sesuai dengan kepadatan relatif yang diinginkan. Dimana, relative compaction (RC) merupakan rasio dari berat volume kering dilapangan terhadap berat volume kering maksimum dari hasil pengujian laboratorium, pada acuan spesifikasi yang sama. Berdasarkan nilai RC tersebut dapat ditentukan kepadatan yang diinginkan untuk diaplikasikan dilapangan, berdasarkan hasil dari laboratorium. Dari hasil analisa berat volume kering dari pengujian kompaksi menggunakan Standard Proctor, material campuran yang baik bagi pekerjaan timbunan adalah material dengan presentase tanah residual $10 \%$ hingga $30 \%$. Berat volume kering maksimum material dengan presentase tanah residual sebesar $10 \%$ mendekati kepadatan maksimum material dengan tanah residual sebesar 30\% dengan selisih sebesar $1,3 \%$.

Jika hanya dilihat dari kepadatan maksimum yang dihasilkan pada masing-masing material campuran, maka material dengan presentase tanah residual $10 \%$ sampai dengan 30\% merupakan material yang baik untuk digunakan sebagai material timbunan. Namun, dalam menentukan salah satu material campuran yang akan digunakan dalam pekerjaan timbunan sebaiknya juga harus ditinjau dari beberapa aspek, antara lain;

\section{Lokasi}

Jika suatu lokasi timbunan material pasirlebih mudah didapatkan dan didatangkan daripada material tanah residual, maka material campuran yang direkomendasikan adalah komposisi 90\% pasir dengan $10 \%$ tanah residual.

2. Biaya

Pada umumnya, material campuran dengan presentase pasir yang lebih tinggi mempunyai harga yang lebih mahal. Oleh karena itu, material yang direkomendasikan adalah komposisi $70 \%$ pasir dengan 30\% tanah residual.

\section{Kadar air}

Kadar air natural $\left(w_{n}\right)$ dari material campuran yang akan digunakan harus diketahui terlebih dahulu. Jika material campuran memiliki wn yang jauh lebih kecil dari wopt, maka diperlukan tambahan air untuk mencapai kepadatan yang diinginkan. Keberadaan air dalam suatu lokasi timbunan juga menjadi pertimbangan dalam menentukan material campuran, karena berfungsi untuk mendekatkan nilai wn terhadap wopt. Material timbunan yang memiliki wn mendekati wopt akan mempersingkat waktu pemadatan, tanpa harus menambahkan air sebelumnya. Material timbunan yang dipilih disesuaikan dengan kebutuhan dan keadaan dilapangan.

Dalam menentukan suatu material campuran yang digunakan sebagai material timbunan, juga perlu dilakukan analisis dari ketiga aspek tersebut, sehingga dapat ditentukan material campuran yang paling efisien yaitu campuran yang menghasilkan kepadatan yang tinggi dengan biaya yang paling ekonomis.

\section{KESIMPULAN}

Berdasarkan pengujian, pembahasan, dan analisis yang dilakukan, dapat disimpulkan sebagai berikut:

1. Kandungan butir halus dalam material campuran berpengaruh terhadap bentuk lengkung kompaksi.

2. Peningkatan material butir halus mengakibatkan penurunan kepadatan material campuran.

3. Sebaliknya, peningkatan material butir halus mengakibatkan peningkatan kadar air optimum material campuran.

4. Berdasarkan nilai kepadatan maksimum (MDD) yang dibentuk pada kadar air optimum (OMC), material dengan presentase tanah residual 10\%, $201 \%$, dan 30\% mempunyai nilai tertinggi yang saling mendekati satu sama lain, sehingga dapat direkomendasikan menjadi material yang dapat digunakan dalam pekerjaan timbunan. Untuk menentukan penggunaan salah satu dari ketiga material tersebut, dibutuhkan peninjauan kembali sesuai dengan kondisi dan kebutuhan lapangan.

\section{UCAPAN TERIMA KASIH}

Ucapan terima kasih disampaikan kepada pihak Jurusan Teknik Sipil Institut Teknologi Bandung atas kesempatan yang diberikan dalam melakukan pengujian pada Laboratorium Mekanika Tanah, serta Fakultas Teknik Universitas Pancasila yang telah memberikan kesempatan bagi penulis untuk melakukan publikasi ini.

\section{REFERENSI}

ASTM D 698-91. (1999). Standard Test Methods for Laboratory Compaction Characteristics of Soil Using Standard Effort. Annual Book of ASTM Standard Section 4. Vol.04.08. ASTM International, West Conshohocken, PA, pp.78-85

Budhu, M. (2007). Soil Mechanics and Foundations, John Wiley and Sons, Inc, United States of America. 
Chen, Y. (2010). An Experimental Investigation of the Behavior of Compacted Clay/Sand Mixtures. Thesis, University of Delaware.

Das, B, M. (2008). Fundamentals of Geotechnical Engineering, Thomson Learning, part of the Thomson Corporation, United States of America.

Kim, D., Sagong, M., Lee, Y. (2005). Effects of Fine Aggregate Content on the Mechanical Properties of the Compacted Decomposed Granitic Soil, Construction and Building Materials 19, 189-196.

Horpibulsuk, S., Suddeepong, A., Chamket, P., Chinkulkijniwat, A. (2013). Compaction Behavior of Fine-Grained Soils, Lateric Soils, and Crushed Rocks. The Japanese Geotechnical Society, Soils and Fondation 53(1): 166-172.

Prasanna, H.S. (2017). Correlation of Compaction Characteristics of Fine-Grained Soils using Atterberg Limits. International Journal of Engineering Research \& Technology, Vol. 6 Issue 06.

Sridharan, A., Nagaraj, H.B. (2005). Plastic Limit and Compaction Characteristic of Fine Grained Soils. Ground Improvement No.1, 17-22.

Wesley, L.D. (2010). Geotechnical Engineering in Residual Soils. John Wiley and Sons, Inc. United States of America. 